VARIABEL VOL. 2 NO. 1 (2019): 1-8

p-ISSN: 2593-302X dan e-ISSN: 2599-3038

This work is licensed under

a Creative Commons Attribution-NonCommercial 4.0 International License.

\title{
Pengaruh Model Discovery Learning terhadap Pemahaman Konsep Matematis Siswa pada Materi Persamaan Lingkaran di Kelas XI IPA
}

\author{
Ani Trianingsih $^{1}$, Nurul Husna ${ }^{2}$, Nindy Citroresmi Prihatiningtyas ${ }^{3}$ \\ STKIP Singkawang, Singkawang, Indonesia \\ anitrianingsih01@gmail.com ${ }^{1}$, nuna_husna@ymail.com ${ }^{2}$, nindy.citroresmi@yahoo.com ${ }^{3}$
}

\author{
Kata Kunci : \\ Discovery Learning, \\ Pemahaman Konsep \\ Matematis, Aktivitas Siswa
}

\begin{abstract}
ABSTRAK
Penelitian ini bertujuan untuk mengetahui pengaruh model discovery learning pada materi persamaan lingkaran di kelas XI IPA SMA Negeri 5 Singkawang. Penelitian ini menggunakan desain Pre-Eksperimental dengan bentuk One-Group Pretest-Posttest Design. Populasi dalam penelitian ini adalah seluruh siswa kelas kelas XI IPA SMA Negeri 5 Singkawang yang berjumlah 20 orang siswa. Adapun teknik pengambilan sampelnya dengan Non probability Sampling yaitu sampling jenuh. Karena kelas XI IPA hanya ada satu kelas di SMA Negeri 5, maka sampelnya juga seluruh siswa kelas XI IPA yang berjumlah 20 orang siswa. Analisis yang dilakukan dalam penelitian ini untuk mengetahui pengaruh model discovery learning terhadap kemampuan pemahaman konsep matematis siswa dengan menggunakan uji statistik yaitu sampel paired test. Hasil analisis menunjukkan adanya pengaruh model discovery learning terhadap pemahaman konsep matematis siswa sebesar 2,36\%. Lembar observasi aktivitas belajar siswa dengan model discovery learning menggunakan perhitungan persentase frekuensi aktivitas. Hasil analisis menunjukkan adanya peningkatan aktivitas belajar siswa, dimana pada pertemuan pertama diperoleh persentasenya sebesar 76,88\% dan pertemuan kedua sebesar 79,37\% dengan kriteria sangat aktif. Analisis lembar observasi keterlaksanaan model discovery learning menggunakan perhitungan persentase frekuensi keterlaksanaan. Hasil analisis lembar observasi keterlaksanaan model discovery learning diperoleh persentasenya sebesar $82,63 \%$ dengan kriteria sangat baik.
\end{abstract}

\section{PENDAHULUAN}

Mata pelajaran matematika perlu diberikan kepada semua peserta didik mulai dari sekolah dasar untuk membekali peserta didik dengan kemampuan berpikir logis, analitis, sistematis, kritis, dan kreatif, serta kemampuan bekerjasama (Permendiknas, 2006). Keberhasilan siswa dalam mempelajari matematika satu diantaranya dapat dilihat dari penguasaan siswa terhadap pemahamn konsep. Sesuai dengan Kurikulum Tingkat Satuan Pendidikan (KTSP) tahun 2006 yang menyatakan satu diantara tujuan mata pelajaran matematika adalah memahami konsep matematika, menjelaskan keterkaitan 
antar konsep, dan mengaplikasikan konsep atau algoritma secara luwes, akurat, efesien, dan pemecahan masalah. Menurut Alfiana (2014) pemahaman konsep matematis adalah kompetensi yang ditunjukkan peserta didik dalam memahami konsep dan dapat menyatakan konsep yang sudah ada secara luwes, akurat, efesien dan tepat dalam pemecahan masalah.

National Council of Teacher of Mathematics (NCTM,2000) menyatakan bahwa pemahaman konsep merupakan satu diantara komponen penting kecakapan bermatematika. Sejalan dengan hal tersebut menurut Jihad dkk. (2012) satu diantara kecakapan atau kemahiran matematika yang diharapkan dalam pembelajaran matematika adalah pemahaman konsep. Pentingnya pemahaman konsep dalam proses belajar mengajar sangat mempengaruhi sikap, keputusan, dan cara-cara memecahkan masalah (Trianto,2008). Maka dapat disimpulkan bahwa kemampuan pemahaman konsep matematis dalam pembelajaran matematika merupakan hal yang penting dan harus dimiliki oleh setiap siswa karena pemahaman konsep merupakan kemahiran yang diharapkan dalam pembelajaran matematika dan juga mempengaruhi cara siswa dalam memecahkan masalah.

Adapun indikator kemampuan pemahaman konsep secara umum menurut Kurikulum Tingkat Satuan Pendidikan (KTSP) tahun 2006 yaitu sebagai berikut 1) Menyatakan ulang sebuah konsep; 2) Mengklasifikasikan objek-objek menurut sifat-sifat tertentu (sesuai dengan konsepnya); 3) Memberikan contoh dan non contoh dari suatu konsep; 4)Menyajikan konsep dalamberbagai bentuk representasi matematis; 5) Mengembangkan syarat perlu atau syarat cukup suatu konsep; 6) Menggunakan, memanfaatkan, dan memilih prosedur atau operasi tertentu; 7) Mengaplikasikan konsep atau algoritma pemecahan masalah (Permendiknas, 2006).

Pada kenyataannya kemampuan pemahamn konsep matematis siswa masih tergolong lemah. Berdasarkan hasil penelitian yang dilakukan oleh Kamariah dkk (2013) dapat diketahui bahwa pemahaman konsep matematis siwa masih sangat rendah. Sejalan dengan hal tersebut lemahnya pemahaman konsep siswa juga terjadi di SMA Negeri 5 Singkawang yang ditunjukkan oleh hasil prariset yang dilakukan peneliti di SMA Negeri 5 Singkawang pada hari senin tanggal 18 juli 2016 terhadap 20 siswa, peneliti memberikan soal yang memuat 3 indikator pemahaman konsep matematis siswa yaitu; 1) menyatakan ulang sebuah konsep; 2) memberikan contoh dan non contoh dari suatu konsep; 3) mengaplikasikan konsep atau algoritma pemecahan masalah. Dari data yang diperoleh, peneliti menemukan bahwa sebanyak 12 orang siswa atau $60 \%$ siswa lemah dalam menyatakan ulang sebuah konsep, sebanyak 15 orang siswa atau $75 \%$ lemah dalam memberikan contoh dan non contoh dari suatu konsep, sebanyak 18 siswa atau 75\% siswa masih lemah dalam mengaplikasikan konsep atau algoritma pemecahan masalah. Sehingga dari keseluruhan hasil prariset tentang kemampuan pemahaman konsep siswa dapat diketahui bahwa sebanyak 15 orang siswa atau $75 \%$ siswa masih lemah dalam memahami konsep, kemudian dapat disimpulkan bahwa kemampuan pemahaman konsep siswa kelas XI IPA SMA Negeri 5 Singkawang masih tergolong rendah.

Apabila kondisi demikian terus berlanjut, maka dapat berdampak buruk terhadap kualitas pembelajaran siswa pada materi-materi berikutnya, satu diantaranya yaitu materi persamaan lingkaran. Persamaan lingkaran merupakan bagian dari materi matematika SMA kelas XI IPA. Berdasarkan hasil wawancara yang dilakukan oleh peneliti kepada guru matematika kelas XI IPA terkait materi persamaan lingkaran, beliau mengatakan bahwa pada materi persamaan lingkaran, saat siswa diberikan permasalahan terkait materi persamaan lingkaran, mereka masih kesulitan untuk memecahkan masalah tersebut yaitu dikarenakan siswa masih belum mampu memahami dengan baik konsep dari persamaan lingkaran. Hal tersebut dibuktikan dari hasil ulangan sebelumnya mengenai materi persamaan lingkaran yang masih tergolong rendah. Selain itu peneliti juga melakukan observasi dan menemukan beberapa hal yaitu siswa masih kurang aktif dalam proses kegiatan belajar. Pada saat siswa ditawarkan untuk mengerjakan soal di depan kelas, banyak siswa yang tidak mau dan hanya 3 orang siswa dari 20 siswa yang bertanya kepada guru saat mereka tidak mengerti dengan penjelasan guru. Padahal disetiap proses pembelajaran aktivitas siswa merupakan bagian yang sangat diperlukan. Hal ini sejalan dengan Kemendikbud (2014) menyatakan bahwa pembelajaran matematika yang diharapkan dalam praktek pembelajaran di kelas adalah pembelajaran berpusat pada aktivitas belajar 
siswa. Masalah lain yang ditemukan peneliti adalah proses belajar mengajar masih belum terlaksana dengan baik. Selama proses pembelajaran berlangsung guru tidak melakukan kegiatan apersepsi dan tujuan pembelajaran juga tidak disampaikan, melainkan guru langsung menyampaikan materi, kemudian memberikan latihan, membahas latihan tersebut, dan di akhir pembelajaran juga tidak ada kegiatan menyimpulkan pembelajaran.

Berdasarkan masalah yang dipaparkan mengisyaratkan bahwa pemahaman konsep matematis perlu mendapatkan perhatian yang lebih. Sehingga diperlukan solusi untuk masalah tersebut yaitu dengan memilih model pembelajaran yang tepat. Satu diantara model pembelajaran yang diharapkan dapat berpengaruh terhadap pemahaman konsep matematis siswa adalah discovery learning. Discovery learning merupakan satu diantara implementasi kurikulum 2013. Discovery learning adalah teori belajar yang didefinisakan sebagai proses pembelajaran yang terjadi bila pelajar tidak disajikan dengan pelajaran dalam bentuk finalnya, tetapi diharapkan mengorganisasi sendiri (Permendikbud,2013). Sutrisno (2014) menyatakan bahwa discovery learning merupakan proses pembelajaran yang menekankan siswa dalam menemukan konsep sehingga siswa yang dapat menemukan konsep secara mandiri akan berdampak positif terhadap kemampuan pemahaman konsep matematis. Menurut Kemendikbud (2013) model discovery learning memiliki kelebihan sebagai berikut; 1) membantu peserta didik untuk memperbaiki dan meningkatkan keterampilan-keterampilan dan proses-proses kognitif; 2) peserta didik akan mengerti konsep dasar dan ide-ide lebih baik; 3) menyebabkan peserta didik mengarahkan kegiatan belajarnya sendiri dengan melibatkan akalnya dan motivasi sendiri; 4) menumbuhkan rasa senang pada peserta didik, karena tumbuhnya rasa menyelidiki dan berhasil.

Adapun keterkaitan antara model discovery learning dengan kemampuan pemahaman konsep matematis siswa terdapat pada langkah ketiga, empat, dan enam. Pada langkah ketiga yaitu pengumpulan data dan setelah data terkumpul yang diharapkan dapat memberikan contoh dan bukan contoh dari suatu konsep, tahap selanjutnya siswa mengolah data yang terkumpul yang diharapkan dapat mengembangkan pengetahuan siswa tentang materi yang sedang dipelajari dengan cara memberikan berbagai bentuk permasalahan, dengan demikian siswa dapat mengaplikasikan konsep kepemecahan masalah, dan tahap terakhir siswa didorong untuk menarik kesimpulantentang materi yang sudah didapat sehingga siswa nantinya dapat menyatakan ulang sebuah konsep menurut pemahaman mereka sendiri.

Penerapan model discovery learning dalam pembelajaran matematika memberikan dampak yang positif terhadap kemampuan pemahaman konsep matematis siswa. Berdasarkan penelitian yang dilakukan oleh Asnita (2014) menunjukkan bahwa terdapat pengaruh pemahaman konsep matematis siswa dengan menerapkan model discovery learning. Hasil penelitian yang dilakukan Supriyanto (2014) menunjukkan bahwa aktivitas dan hasil belajar siswa mengalami peningkatan dengan menggunakan model discovery learning. Selain itu penelitian yang dilakukan Alex dan Olubusuyi (2013) menunjukkan bahwa adanya perbedaan yang signifikan dalam mendukung mereka yang menggunakan strategi guided-discovery learning dibanding mereka yang tidak menggunakan guideddiscovery learning. Berdasarkan masalah latar belakang yang telah diuraikan di atas maka peneliti melakukan penelitian lebih lanjut yang berjudul "Pengaruh Model Discovery Learning Terhadap Pemahaman Konsep Matematis Siswa Pada Materi Persamaan Lingkaran di Kelas XI IPA”.

\section{METODE PENELITIAN}

Metode penelitian yang digunakan dalam penelitian ini adalah metode aksperimen dengan pendekatan kuantitatif. Bentuk penelitian yang digunakan dalam penelitian ini adalah pre-eksperimental dengan desain yaitu one-group pretest-posttest desain dikarenakan fokus dalam penelitian ini adalah untuk mengetahui pemahaman konsep matematis setelah dikenakan model discovery learning. Adapun sekolah yang menjadi tempat penelitian adalah SMA Negeri 5 Singkawang kelas XI IPA yang beralamat di Jln. Ratu Sepudak Sungai Rasau Singkawang Utara. Populasi yang digunakan dalam penelitian ini adalah seluruh siswa kelas XI IPA yang berjumlah 20 siswa. Teknik pengambilan sampel yang digunakan adalah Non Probability Sampling yaitu sampling jenuh. 
Teknik analisis data yang digunakan dalam penelitian ini adalah analisis kuantitatif dengan statistika. Dalam penelitian ini akan diperoleh data kuantitatif sehingga untuk menganalisis data didapatkan dari pemberian tes hasil belajar, pengamatan menggunakanlembar aktivitas dan lembar keterlaksanaan pebelajaran.

\section{HASIL DAN PEMBAHASAN}

\section{Kemampuan Pemahaman Konsep Matematis Siswa}

Data yang disajikan dalam penelitian ini adalah data hasil tes pemahaman konsepmatemaatis siswa yang diukur berdasarkan pada indikator pemahaman konsep matematis yang berupa pre-test dan posttest. Adapun indikator pemahamn konsep dalam penelitian ini antara lain: 1) menyatakan ulang sebuah konsep dengan skor 4; 2) memberikan contoh dan non contoh dari suatu konsep dengan skor 4;3) mengaplikasikan konsep pemecahan masalah dengan skor 4 yang terdiri dari 6 buah essay dengan total skor 24. Dari hasil pre-test dan post-test yang diperoleh siswa pada penelitian ini dapat diperjelas pada Gambar 1. Dari Gambar 1 diketahui bahwa persentase untuk setiap indikator pemahaman konsep matematis siswa pada soal pre-test lebih kecil dari persentase soal post-test.

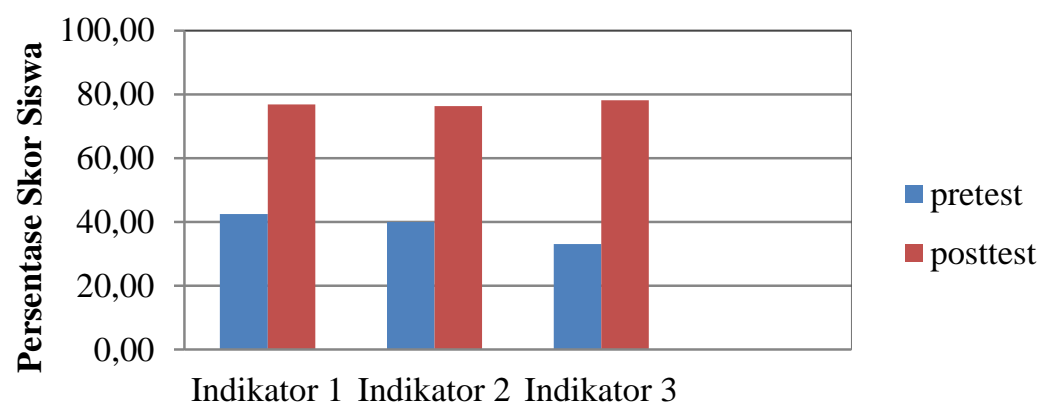

Pemahaman Konsep

\section{Gambar 1.Diagram Batang Persentase Skor Siswa Perindikator Pemahaman Konsep}

Berdasarkan hasil perhitungan, untuk soal pre-test dan post test diperoleh nilai $x_{\text {hitung }}^{2}<x_{\text {tabel }}^{2}$ maka data berdistribusi normal. Jadi dapat disimpulkan bahwa data pre-test dan post-test berdistribusi normal. Untuk perhitungan lebih rinci dapat dilihat dilampiran E-3. Setelah data pre-test dan post-test berditribusi normal, maka dilanjutkan dengan uji paired t-test untuk menguji hipotesis. Berdasarkan hasil analisis menunjukkan bahwa $-t_{\text {tabel }}>-t_{\text {hitung }}$. Dengan demikian $\mathrm{H}_{0}$ ditolak dan $\mathrm{H}_{\mathrm{a}}$ diterima, artinya terdapat perbedaan sebelum perlakuan (pre-test) dan sesudah perlakuan (post-test), sehingga dapat disimpulkan bahwa model discovery learning berpengaruh terhadap pemahaman konsep matematis siswa pada materi persamaan lingkaran di kelas XI IPA SMA Negeri 5 Singkawang. Hal ini berdasarkan mengenai teori perkembangan Piaget, terdapat implementasi penting dalam model pembelajaran satu diantaranya memperhatikan peranan pelik dari inisiatif anak sendiri, keterlibatan aktif dalam kegiatan pembelajaran, tidak menekankan pengetahuan jadi melainkan anak didorong menemukan sendiri pengetahuan itu melalui interaksi spontan dengan lingkungannya (Trianto,2008). Hal ini sejalan mengenai model pembelajaran discovery learning yang memberikan kesempatan kepada siswa dalam mengembangkan dan menemukan pemahamannya sendiri sehingga pembelajaran menjadi bermakna, informasi-informasi yang disajikan mudah diserap, diproses dan disimpan dengan baik oleh sistem memori siswa serta memberikan kesempatan kepada siswa untuk lebih banyak berperan secara aktif di kelas (Ahmad,2015). Hal ini menunjukkan bahwa model pembelajaran discovery learning berpengaruh terhadap pemahaman konsep matematis siswa.

Hasil ini sejalan dengan penelitian yang dilakukan oleh Asnita (2014) yang menyimpulkan bahwa terdapat pengaruh pemahaman konsep matematis siswa dengan menerapkan model pembelajaran discovery learning. Hal ini menunjukkan bahwa model pembelajaran discovery learning berpengaruh terhadap pemahaman konsep matematis siswa. 


\section{Aktivitas Belajar Siswa}

Lembar observasi digunakan untuk mengetahui aktivitas siswa selama mengikuti pembelajaran dengan menggunakan model discovery learning.Pengamatan yang dilakukan selama dua kali pertemuan uang dilakukan oleh 2 orang observer. Hasil observasi aktivitas belajar siswa dilakukan oleh peneliti dengan menggunakan model discovery learning, dapat diperjelas pada Gambar 2. Dari Gambar 2 menunjukkan bahwa aktivitas siswa selama pembelajaran berlangsung mengalami peningkatan.

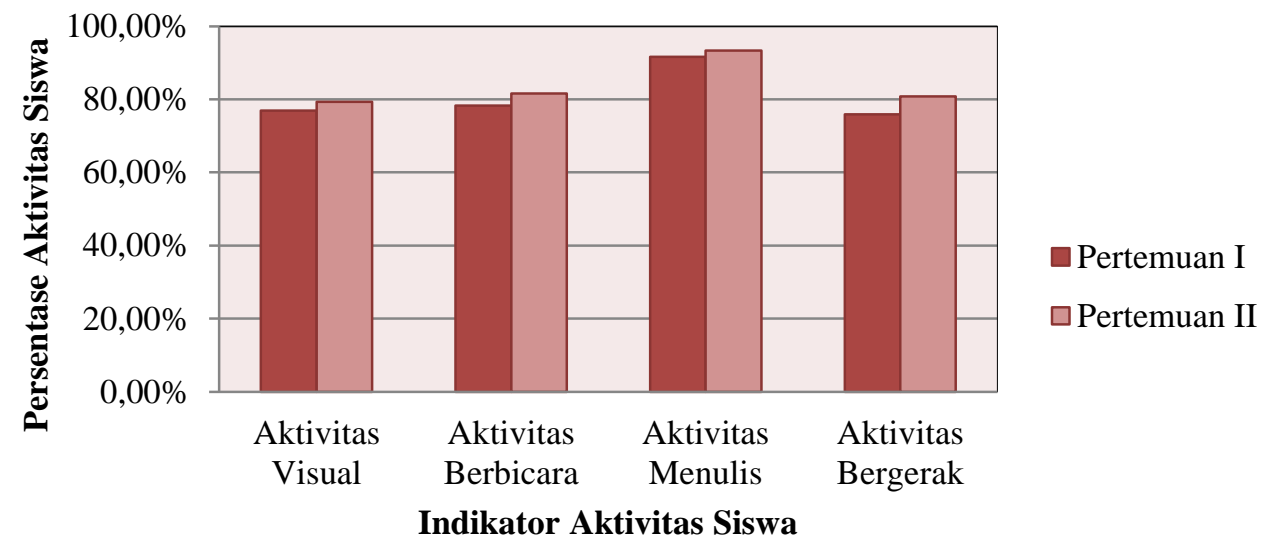

Gambar 2.Diagram Persentase Aktivitas Siswa

Pengamatan pada lembar observasi aktivitas siswa yang dilakukan dengan model pembelajaran discovery learning sebanyak dua kali pertemuan yang diamati oleh dua orang observer yaitu satu orang guru dan satu orang mahasiswa. Perhitungan untuk mengetahui aktivitas belajar siswa menggunakan rumus persentase frekuensi aktivitas. Hasil observasi yang dilakukan untuk pertemuan kedua yaitu pengamatan untuk kategori aktivitas visual dengan empat aktivitas yang diamati yaitu siswa membaca materi yang disampaikan pada buku pegangan siswa, mendengar penjelasan/instruksi guru, mengamati permasalahan yang diberikan guru, dan mendengarkan penjelasan dari teman, persentasenya lebih besar dari pertemuan pertama. Pada kategori aktivitas berbicara dengan enam aktivitas untuk pertemuan kedua yang diamati yaitu siswa menjelaskan materi kepada teman kelompok, mempresentasikan hasil diskusi kepada kelompok lain, menyampaikan pendapat saat berdiskusi, menjawab pertanyaan jika mengetahui jawabannya, bertanya jika belum mengerti, dan memberika kesimpulan materi yang dipelajari, persentasenya lebih dari pertemuan pertama.

Pada kategori pengamatan aktivitas menulis untuk pertemuan kedua yang terdiri dari tiga aktivitas yang diamati yaitu siswa mencatat soal yang diberikan guru, mengerjakan soal yang diberikan guru, dan mencatat kesimpulan dari hasil belajarnya diperoleh hasil persentasenya lebih dari pertemuan pertama. Pada kategori pengamatan aktivitas bergerak yang terdiri dari tiga aktivitas yang diamati yaitu siswa maju kedepan untuk mempresentasikan hasil diskusinya, berdiri dan membentuk kelompok, dan mengangkat tangan saat ingin bertanya atau menyampaikan pendapat diperoleh persentase pertemuan kedua lebih besar dari pertemuan pertama.

Berdasarkan data persentase aktivitas siswa, diperoleh rata-rata untuk pertemuan pertama dari keempat kategori pengamatan dan dua orang observer, persentasenya kurang dari pertemuan kedua. Hal ini berarti bahwa aktivitas siswa selama pembelajaran berlangsung berada pada kategori sangat aktif. Maka dapat disimpulkan bahwa aktivitas belajar siswa setelah diberikan model pembelajaran discovery learning menjadi aktif pada materi persamaan lingkaran di kelas XI IPA SMA Negeri 5 Singkawang.

Hal ini berdasarkan mengenai teori Bruner yang menyatakan agar siswa hendaknya belajar melalui partisipasi secara aktif dengan konsep-konsep dan prinsip-prinsip, agar mereka dianjurkan untuk 
memperoleh pengalaman, dan melakukan eksperimen-eksperimen yang mengizinkan mereka untuk menemukan prinsip-prinsip itu sendiri (Trianto, 2008). Berdasarkan pernyataan tersebut model pembelajaran discovery learning merupakan proses pembelajaran yang terjadi bila siswa tidak disajikan matreri dalam bentuk finalnya, tetapi diharapkan mengorganisasi sendiri. Hal ini menunjukkan bahwa aktivitas belajar siswa dengan model pembelajaran discovery learning menjadi aktif.

Hal ini sejalan dengan penelitian yang dilakukan oleh Supriyanto (2014) menunjukkan bahwa terdapat peningkatan aktivitas dan hasil belajar siswa dengan menggunakan model pembelajaran discovery learning. Hal ini menunjukkan bahwa model pembelajaran discovery learning berpengaruh positif terhadap aktivitas belajar siswa.

\section{Keterlaksanaan Pembelajaran Siswa}

Observasi yang dilakukan dalam penelitian ini adalah untuk mengetahui keterlaksanaan pembelajaran dengan menggunakan model discovery learning pada materi persamaan lingkaran yang ada di dalam RPP. Observasi yang dilakukan dengan menggunakan lembar observasi yang telah disusun, dimana semua indikator yang diobservasi dalam penelitian ini dikembangkan dari setiap langkah-langkah pembelajaran yang dimiliki oleh model discovery learning yang dilakukan sebanyak dua kali pertemuan pertemuan yang dilakukan oleh 2 orang observer. Adapun hasil analissis penelitian data lembar keterlaksanaan model discovery learning di tampilkan pada Tabel 1.

Tabel 1. Presentase Observasi Keterlaksanaan Pembelajaran Model Discovery Learning

\begin{tabular}{lccc}
\hline \multirow{2}{*}{ Model Discovery } & \multicolumn{2}{c}{ Pertemuan } & \multirow{2}{*}{ Rata-rata } \\
\cline { 2 - 3 } & $\mathbf{1}$ & $\mathbf{2}$ & \\
\hline Jumlah Skor & 57,5 & 59,5 & 58,5 \\
Skor Maksimal & 4 & 4 & \\
Jumlah Item & 18 & 18 & \\
Persentase (\%) & $79,85 \%$ & $82,63 \%$ & 81,24 \\
Kriteria & Sangat Baik & Sangat Baik & Sangat Baik \\
\hline
\end{tabular}

Tabel 1 menunjukkan bahwa persentase untuk pertemuan pertama lebih kecil dari persentase pertemuan kedua, hal ini menunjukkan bahwa pembelajaran matematika dengan menggunakan model discovery learning dapat terlaksana dengan baik pada materi persamaan lingkaran. Pengamatan pada lembar observasi keterlaksanaan pembelajaran siswa yang dilakukan dengan model pembelajaran discovery learning sebanyak dua kali pertemuan yang diamati oleh dua observer yaitu satu orang guru dan satu orang mahasiswa. Perhitungan untuk mengetahui keterlaksanaan model discovery learning terlaksana dengan baik maka akan digunakan rumus persentase frekuensi keterlaksanaan. Berdasarkan hasil pada pertemuan pertama dan kedua keterlaksanaan pembelajaran diperoleh persentase rata-rata keterlaksanaan yaitu persentasenya pertemuan pertama kurang dari pertemuan kedua. Hal ini menunjukkan bahwa keterlaksanaan model pembelajaran discovery learning selama pembelajaran berlangsung berada pada kriteria sangat baik. Hal ini berarti bahwa pembelajaran discovery learning dapat terlaksana dengan baik pada materi persamaan lingkaran di kelas XI IPA SMA Negeri 5 Singkawang. Hasil ini sejalan dengan penelitian yang dilakukan oleh Arinawati (2014) yang menyimpulkan bahwa model pembelajaran discovery learning berpengaruh terhadap hasil belajar siswa. Model pembelajaran discovery learning yang memberikan kesempatan kepada siswa dalam mengembangkan dan menemukan pemahamannya sendiri sehingga pembelajaran menjadi bermakna, informasi-informasi yang disajikan mudah diserap, diproses dan disimpan dengan baik oleh sistem memori siswa serta memberikan kesempatan kepada siswa untuk lebih banyak berperan secara aktif di kelas (Ahmad,2015). Hal ini menunjukkan bahwa model pembelajaran discovery learning berpengaruh terhadap keterlaksanaan pembelajaran siswa. 


\section{KESIMPULAN}

Berdasarkan analisis data hasil penelitian yang dilakukan dan pembahasan secara umum dapat disimpulkan bahwa model discovery learning berpengaruh terhadap pemahaman konsep matematis siswa pada materi persamaan lingkaran di kelas XI IPA SMA Negeri 5 Singkawang. Secara khusus disimpulkan bahwa terdapat perbedaan pemahaman konsep matematis siswa antara sebelum dan setelah perlakuan dengan model discovery learning pada materi persamaan lingkaran di kelas XI IPA SMA Negeri 5 Singkawang, aktivitas belajar siswa mengalami peningkatan setelah diberikan model discovery learning untuk pertemuan pertama sebesar 75,8\% dan pertemuan kedua sebesar $80 \%$, sehingga aktivitas belajar siswa menjadi sangat aktif pada materi persamaan lingkaran di kelas XI IPA SMA Negeri 5 Singkawang, pembelajaran matematika dengan menggunakan model discovery learning dapat terlaksana dengan baik pada materi persamaan lingkaran di kelas XI IPA SMA Negeri 5 Singkawang.

\section{UCAPAN TERIMAKASIH}

Peneliti mengucapkan terimakasih kepada Ibu Dra. Aprilyanti sebagai kepala sekolah SMA Negeri 5 Singkawang yang telah memberikan izin untuk melakukan penelitian dan Bapak M. Marjuansyah, S.Pd selaku guru kelas yang sangat membantu dalam memberikan informasi tentang siswa di sekolah.

\section{DAFTAR PUSTAKA}

Ahmad, H. (2015). Peningkatan Kemampuan Penalaran Matematika Materi Trigonometri melalui Penerapan Model Pembelajaran Discovery Learning dengan Pendekatan Saintifik pada Kelas X SMA Negeri 11 Makassar. Jurnal Daya Matematis, 3(3), 299-307.

Alex, M.A., \& Olubusuyi, M.F. (2013). Guided-discovery Learning Strategy and Senior School Students Performance in Mathematics in Ejigbo, Nigeria. Journal of Education and Practice, 4(12), 82-90.

Arinawati, E. (2014). Pengaruh Model Pembelajaran Discovery Learning terhadap Hasil Belajar Matematika ditinjau dari Motivasi Belajar. Artikel Penelitian. Surakarta: PGSD FKIP Universitas Sebelas Maret Surakarta.

Asnita, Y. (2014). Pengaruh Model Discovery Learning Menggunakan True or False Statement Terhadap Pemahaman Konsep Matematis Siswa Kelas VIII MTsN Tanjung Balit Kabupaten Solok. Artikel Penelitian. Padang: STKIP PGRI Sumatera Barat.

Alfiana, F. (2015). Analisis Kemampuan Pemahaman Konsep Matematis Siswa Kelas VII SMP Negeri 2 Binangun pada Materi Bilangan Bulat. Artikel Penelitian. Purwokerto: Universitas Muhammadiah Purwokerto.

Jihad, \& Asep. (2012). Evaluasi Pembelajaran. Yogyakarta: Multi Pressindo.

Kamariah, N. Hudiono, B. \& Yani, A. (2013). Pemahaman Konseptual Matematis Siswa pada Materi Kubus di Kelas XI SMPS Bumi Khatulistiwa. Artikel Penelitian. Pontianak: FKIP Untan.

Kemendikbud. (2013). Pendekatan dan Strategi Pembelajaran SD/SMP/SMA/SMK. Jakarta: Kemendikbud.

Kemendikbud. (2014). Peraturan Menteri Pendidikan dan Kebudayaan Nomor 59 Tahun 2014 Tentang Kurikulum 2013 Sekolah Menengah Atas/Madrasah Aliyah. Jakarta: Kemendikbud.

National Council of Teacher of Mathematics (NCTM). (2000). Principles Standars For School Mathematics, Virginia: Reston.

Permendiknas. (2006). Peraturan Mentri Pendidikan Nasional Republik Indonesia Nomor 22 Tahun 2006 tentang Standar Isi untuk Satuan Pendidikan Dasar dan Menengah. Jakarta: Kemendiknas.

Permendikbud. (2013).Standar Proses Pendidikan Dasar dan Menengah Nomor 65 Tahun 2013. Jakarta: Kemendikbud.

Supriyanto, B. (2014). Penerapan Discovery Learning untuk Meningkatkan Hasil Belajar Siswa Kelas VI Mata Pelajaran Matematika Pokok Bahasan Keliling dan Luas Lingkaran. Artikel Penelitian. Jember. 
VARIABEL Vol. 2 No. 1 (2019)

Page: $1-8$

Sutrisno, J. (2014). Pengaruh Pembelajaran Discovery Learning Berbantu Alat Peraga Persegi Pythagoras terhadap Kemampuan Pemahaman Konsep Matematis Siswa SMP. Artikel Penelitian. Purwokerto:UM Purwokerto.

Trianto. (2008). Mendesain Pembelajaran Kontekstual (Contextual Teaching And Learning) di Kelas. Jakarta: Cerdas Pustaka Publisher. 